\title{
"Little Monkeys on the Grass..." How People for and Against Evolution Fail to Understand the Theory of Evolution
}

\author{
Steven R. Jakobi
}

Published online: 17 March 2010

(C) Springer Science+Business Media, LLC 2010

\begin{abstract}
In an informal survey, only five percent of 306 college freshmen students in an introductory biology course provided a correct scientific definition for the theory of evolution. The other respondents provided answers that ranged from "organisms improving themselves" (42 percent) to "monkeys becoming humans" (seven percent). Some of the potential reasons for the lack of understanding of the concept of evolution are explored.
\end{abstract}

Keywords Student survey · Freshmen college students . Definition of evolution

Opinion survey polls consistently show that of those Americans who have a stated position on the subject, about 40 percent accept the scientific concept of evolution (Moore 2005; Newport 2009). This, of course, also means that 60 percent of the public rejects it. Yet, after many years of teaching both traditional age and adult students in a variety of settings, I began to suspect that people on both sides of the issue have no clear idea what evolution is. Strong opinions are likely proffered about incorrect concepts. To test this idea, I polled freshmen students in my introductory college biology classes during the first week of the Fall semester during 2005 through 2009, long before I spoke a single word about the subject of evolution. I wanted to see what concepts, knowledge, or dogma they brought with them from their high school days. The college course I teach is a two-semester introductory biology course. Since our college does not offer a separate course

S. R. Jakobi $(\square)$

Physical and Life Sciences Department,

Alfred State College,

10 Upper College Drive,

Alfred, NY 14802, USA

e-mail: jakobisr@alfredstate.edu for our biology majors, I teach students from many twoand four-year programs. The typical lecture class size is 30 40 students per section. Alfred State College (ASC) draws students primarily from western New York State, and anecdotal evidence indicates that more than half of our students are first in their families to attend college. The average combined SAT score (reported by 57 percent of students in 2009) was 971 , and 20 percent of freshmen reported an average score of 21 for the ACT exam. Thus, in terms of demographics and high school performance, ASC resembles a community college student population.

The survey I administered was in no way scientific, nor did I attempt to perform statistical analyses of the results. Yet, the outcome was quite eye-opening, and the results were virtually identical from one year to the next.

The survey worked like this. I gave each student a sheet of paper with three questions. They were asked not to put their names on the paper. The questions were:

1. Please define the word "evolution" to the best of your ability;

2. Now that you wrote a definition, do you agree with this concept? (yes or no);

3. a. If you agree with YOUR definition of evolution, why?

or

b. If you disagree with YOUR definition of evolution, why?

I gave the students five minutes to think about their answers before they wrote anything. Then I asked a student to collect the surveys, and I left the room for about ten minutes. I kept the surveys filed away until the Spring term when I spend about three weeks of classroom instruction on evolution. At the beginning of that unit, I read a few randomly chosen responses to the class as a preamble to the treatment of the subject. 
I collected a total of 306 surveys from seven sections over the five-year time span. As I began to read them, it quickly became apparent that most answers could be grouped based on similar themes, and I eventually sorted the papers into six categories (Table 1). These were (and I include some "typical" answers - complete with spelling and grammatical errors - as points of illustration):

1. Organisms adapt themselves to their surroundings:

Evolution is the process caused by the organism needing to adapt to a changing environment.

...the natural way that things change themselfs to adapt to their surrounding.

One hundred twenty-eight of the 306 respondents (41.8 percent) put answers that fell into this teleological category; 119 of the 128 (93 percent) agreed with their own statements (Table 1). This theme was, by far, the most popular answer.

2. Organisms go from "simple" to "complex" or "advanced":

The process in which living organisms became bigger, better, smarter with the passing of time.

This definition was provided by 40 (13.1 percent) students. All but eight students agreed with the statements they gave.

3. Changes occurred over a long time:

Over long periods of time new things will emerge due to the revolving time period also known as evolution.

The development of any species over long periods of time. They could be small changes or extreme changes.

This type of answer was the choice of 46 (15 percent) students. All but four individuals felt that this was a definition with which they agreed.
4. Apes to humans:

Evolution as I know it is the transformation of animals over time. Specifically Neanderthals into humans. I'm not sure how the classes or stages go but they include primates, neanderthals, cromates, and others I forget.

Twenty-two of the 306 (7.2 percent) students answered something similar to this. Perhaps not surprisingly, nine of the 22 respondents strongly disagreed with their own definition.

\section{5. "Other" answers:}

This category included a variety of answers that I was either unable to characterize, or they made no sense or were ones that hit all previous concepts combined into one answer.

The word evolution to me means how the world has come about and new generations became what they are.

Evolution could mean almost anything. The world, a person, plants even. I think anything can evolve into something. Or become evolutionized.

A total of 54 (17.6 percent) answers were lumped into this group. Since these answers were either meaningless (see above) or confusing, only 34 of 54 students agreed with their own statement; 16 disagreed, and four marked both "agree" and "disagree" boxes (Table 1). Clearly, these individuals were not only confusing but confused, as well.

6. More or less correct answers:

Later on I will define what evolutionary theory means to many biologists, but the answers in this category (16 of 306 students; 5.2 percent) came closest:

Evolution is a process through which a species passes their gene and its biological features to the next generation with some modifications due to the environment.

Thirteen students agreed with their statement, one disagreed, and two both agreed (for all creatures other

Table 1 Results of an informal survey of 306 freshmen biology course students who were asked to define the word "evolution"

\begin{tabular}{|c|c|c|c|c|}
\hline Category of definition of evolution & $\begin{array}{l}\text { Percent of all } \\
\text { students }\end{array}$ & $\begin{array}{l}\text { Percent of students } \\
\text { agreed }\end{array}$ & $\begin{array}{l}\text { Percent of students } \\
\text { disagreed }\end{array}$ & $\begin{array}{l}\text { Percent of students both } \\
\text { agreed/disagreed }\end{array}$ \\
\hline Organisms adapt themselves to changing environments & 41.8 & 92.9 & 7.1 & 0 \\
\hline Organisms change from simple to complex & 13.1 & 80.0 & 20.0 & 0 \\
\hline Process that occurs over a long period of time & 15.1 & 91.3 & 8.7 & 0 \\
\hline The change from apes to humans & 7.2 & 59.1 & 40.9 & 0 \\
\hline "Other" answers & 17.6 & 63.0 & 29.6 & 7.4 \\
\hline "Correct" definition & 5.2 & 81.2 & 6.3 & 12.5 \\
\hline
\end{tabular}

Six categories of answers and the percentages of students who provided those answers are shown in column one. The percentages of students who agreed or disagreed with their own statements are shown in the subsequent columns 
than humans) and disagreed (humans were created separately).

Among those who disagreed with whatever category of answers they provided, most stated religious reasons for doing so, even though I never asked them about their faith or religious orientation. Some of the typical reasons are cited below (again, complete with stylistic and spelling errors):

As a religious person, the Bible states God created the heavens and earth. It was written for Jews that had no scientific [knowledge] of the earth. Thus it would be observed that it would have included the information in Genesis. If God created the universe it seems to me that he could use any method he see fit.

I believe that God created the animals the way he wanted them. I don't believe that dolphins became dogs or that we were once Apes.

So, there you have it. Is this what we have been teaching them in our schools, homes, and houses of worship about evolution? If this is what the general public knows about evolutionary theory, is it any wonder that a majority of the American public doesn't "believe" it? Equally important, as even this nonscientific survey shows, even those individuals who "accept" the concept apparently don't have any idea about what they profess to be true.

I have thought long and hard about why there is this confusion and mistrust about what evolution means. First, I think the problem is one of semantics. The word "evolution" has different meanings in different disciplines. A quick check of the dictionary (Webster's New Universal Unabridged 2001) provided no less than ten different meanings for the word. Included in these were references to "growth and personal development" (in the context of the social scientist's use for personal achievement); a "process of gradual, peaceful, progressive change or development" (the political scientist's use of the term); "movement of troops, ships, etc, for battle" (the military scientist's interpretation); and several other nuanced variations of the above, in addition to the biological definition. Another troubling word is "theory." For the scientist, use of this term is restricted to the context of a rigorous process of hypothesis testing that includes evaluation of experimental data. For the general public, the word has quite a different meaning that can include guesses without any necessary knowledge of facts or analysis of empirical data. It is no wonder, then, that one often hears that "evolution is just a theory, not fact."

Secondly, evolutionary theory has been, at best, misunderstood or simply painted as a canard. Scientists of all stripes - from Galileo to Darwin - have been branded as scoundrels, criminals, or heretics if they dared to deviate from the official dogma of their respective eras. The denunciation in the seventeenth century by the Catholic Church of the Copernican concept of a heliocentric system of planets; the Scopes "Monkey Trial" in 1925 in Tennessee; and the death of the Russian geneticist, Nikolai Vavilov, in a Soviet prison camp in 1943 for being "an enemy of the people" are among the most egregious examples of enforcing the official doctrine of their day. While I'm not a conspiracy theorist at heart, I do believe that powerful forces always want to maintain the status quo and, indeed, go to great lengths to confuse and misinform people. Obfuscation serves a purpose. After all, knowledge is power, and power is not meant to be shared by the rulers.

Thirdly, our educational system and parents have failed our students. Some teachers have inadequate knowledge and understanding of the subject (Rutledge and Mitchell 2002); others don't "believe" in it for their own personal reasons (Berkman et al. 2008); still others are reluctant to broach the topic for fear of stirring up controversy. In high schools, especially, there is no such thing as academic freedom. Parents, school boards, principals, and state legislatures often intimidate or threaten teachers into silence and/or demand the teaching of religion-based concepts on the origins of organisms (US National Science Teachers Association 2005; Cavanagh 2008). Many teachers and teacher organizations fight back, of course, but this is often a very expensive and energy-intensive battle. The end result of these obstacles to good science education is that students are confused and are left with some murky concepts of dinosaurs and ice ages that they acquired from watching Disney movies.

By the time I get around to explaining the basic tenets of evolutionary theory in my classes, we have spent a semester and a half talking about chromosomes, genes, alleles, embryology, biochemistry, the cell theory (interestingly, a "theory" that no one seems to doubt anymore), taxonomy, and a myriad of other topics. In each of these subjects, I attempt to relate the topic to the theme of evolution. Having had the luxury of time to set the stage properly, I finally get around to focusing on evolution for a period of about three weeks. However, before I begin, I tell my students this: "I am not here to convince you of anything. If, at the end of this section you want to reject evolutionary theory for whatever reason, please feel free to do so. I ask only that you understand and know what it is you reject." So, how do I "define" evolution for my students? Like many biologists, I approach the subject initially from a population genetics point of view. I tell them that while individual organisms are not capable of "evolving" or "adapting themselves," there are changes in the genetic makeup of populations over time as a result of mutation, transformation, transduction, crossing over between homologous chromosomes, polyploidy, loss of alleles from small populations, and other processes. I explain that the time period can be long or short, depending on the organism in question. I make a deliberate distinction between shifts in allele frequencies in 
populations "as a result of," rather than "in response to" changes in the environment. I point out that "simple" is not synonymous with "primitive" and that some of the most "successful" organisms are single-celled photosynthetic creatures. I try to clarify that "descent with modification" is not synonymous with "dolphins becoming dogs, or that we were once apes" as one of the survey respondents explained. My approach in explaining evolution is not unique and, in most respects, is not different from many other biology instructors at other colleges and universities. At this time, the students and I revisit some of the survey responses and try to point out the fallacy of some of the answers, or the circular or teleological reasoning that may have constituted their responses. We spend a period discussing some of the answers and why they may have fallen short of an adequate explanation.

My worry is not whether they accept the theory of evolution. What makes me appalled is that only about five percent of the students identified the process at least partly correctly in the first place. Most people have an opinion on the subject of evolution in survey polls, yet, apparently, very few know what they are agreeing or disagreeing with.

I test my classes on the scientific explanation for evolution, including population genetics, Hardy-Weinberg, paleontology, cladistics, natural selection, etc., but I do not ask my students after my lectures whether they were "convinced" by my presentations, or whether they "changed their minds." I do not feel that that is my role, and I want to be respectful of their individual beliefs, whatever those may be. I do hope, however, that they come to their own conclusions, and if they don't agree with the scientific version of the "theory of evolution," then, at least, they know what it is they are rejecting. And I always hope against hope that I will never, ever again see a response like this:

If evolution theory or concept or whatever is true then why don't we keep evolving? ...If the evolution theory is true for humans then why aren't little monkeys sitting outside on the grass evolving into humans?

\section{References}

Berkman MB, Pacheco JS, Plutzer E. Evolution and creationism in American classrooms: a national portrait. PLoSBiology. 2008;6 (5):e124. doi:10.1371/journal. pbio.0060124.

Cavanagh S. "Academic freedom" used as a basis of bills to question evolution. Educ Week. 2008;27:1.

Moore DD. Most Americans tentative about origin of life explanations. The Gallup Poll. 2005. www.pollingreport.com/science. htm

Newport F. On Darwin's birthday, only 4 in 10 believe in evolution. The Gallup Poll. 2009. www.gallup.com/poll/114544/DarwinBirthday-Believe-Evolution.aspx

Rutledge ML, Mitchell MA. High school biology teachers' knowledge structure, acceptance, and teaching of evolution. Am Biol Teach. 2002;64:21-8.

US National Science Teachers Association. Survey indicates science teachers feel pressure to teach nonscientific alternatives to evolution. 2005. http://science.nsta.org/nstaexpress2005_03_28_pressrelease. htm 